\title{
Complete mitochondrial genome of the
} Southern catfish (Silurus meridionalis Chen) and Chinese catfish (S. asotus Linnaeus): Structure, phylogeny, and intraspecific variation

\author{
Q.R. Wang ${ }^{1}$, C. $X u^{2}$, C.R. $X u^{2}$ and R.J. Wang ${ }^{2}$ \\ 1'Department of Biology, Zunyi Normal College, Zunyi, Guizhou, China \\ ${ }^{2}$ College of Life Sciences, Peking University, Beijing, China \\ Corresponding author: R.J. Wang \\ E-mail: rjwang@pku.edu.cn
}

Genet. Mol. Res. 14 (4): 18198-18209 (2015)

Received August 8, 2015

Accepted October 18, 2015

Published December 23, 2015

DOI http://dx.doi.org/10.4238/2015.December.23.7

ABSTRACT. The complete mitochondrial genome of the Southern catfish (Silurus meridionalis) and the Chinese catfish (S. asotus), was determined using the long and accurate polymerase chain reaction (LA-PCR) method. The mitochondrial DNA nucleotide sequences of $S$. meridionalis and $S$. asotus were compared with those of 47 other catfish species in the same order. The total length of mitochondrial DNA for $S$. meridionalis and $S$. asotus was 16,526 and $16,525 \mathrm{bp}$, respectively, and included 13 proteincoding genes, 2 ribosomal RNA genes, 22 transfer RNA genes, and a noncoding control region. This mitochondrial gene arrangement is identical to that observed in other Siluriformes. To determine the relative phylogenetic positions of $S$. meridionalis and $S$. asotus, and to discover phylogenetic relationships among 24 families of Siluriformes, analyses were conducted, based on mitochondrial DNA, 12S ribosomal RNA, 16S ribosomal RNA, and 13 protein-coding gene sequence data sets. Phylogenetic analyses were congruent with a basal split of the order into Clupeiformes, Characiformes, Cypriniformes, and Siluriformes, and supported a closer relationship of the 
Southern catfish (family Siluridae) and the Chinese catfish (family Siluridae) to Pimelodidae than to Bagridae. We concluded that these two species are part of a molecular clade that is different from that proposed in recent studies, in which Amblycipitidae appears as a sister group. Our results showed Amblycipitidae appearing as the most basal extant, and Bagridae appearing as a sister group of Cranoglanididae and Pangasiidae. The Siluriformes showed close phylogenetic relationship to the Characiformes.

Key words: Southern catfish; Chinese catfish; Mitochondrial genome; Phylogeny; Structure; Intraspecific variation

\section{INTRODUCTION}

Catfish (Siluriformes) are widely distributed in every continent worldwide. In China, there are 11 families of the order Siluriformes, in which the family Siluridae is the most widely distributed (Chen, 1977). Of the 13 species of Siluridae in China, the most important economic species include the Southern catfish (Silurus meridionalis, Chen) and the Chinese catfish (S. asotus, Linnaeus) (Chu et al., 1999).

The Southern catfish is endemic to the main channel and tributaries of the Yangtze and Pearl Rivers, whereas the Chinese catfish is distributed worldwide (Chu et al., 1999). To improve the culture of both species, several studies have focused on reproduction (Wei and Luo, 1998), cell biology (Hong and Liu, 1998), and biochemistry (Shirai et al., 2006; Li et al., 2010; Zhang et al., 2010).

Genetic diversity in the wild is crucial for the culture of farmed populations. However, due to overfishing, pollution, and other environmental disturbances, populations of both species have rapidly declined in recent years (Chen, 1977). Therefore, it is important to conserve these species to have a better understanding of the genetic diversity of wild populations.

The random amplified polymorphic DNA (RAPD) method has evaluated the genetic diversity of Chinese catfish (Yoon and Kim, 2004; Li et al., 2009). However, the results based on RAPD are difficult to compare among different studies. By comparison, mitochondrial DNA (mtDNA) is a useful molecular marker for research on population genetics because of its maternal inheritance, relative lack of recombination, and its prompt evolutionary rate, as compared to nuclear DNA (Moore, 1995).

In fish, several mitochondrial genes have been employed for population genetic studies, such as cytochrome $b$ (Cytb) and 16S rRNA genes (Peng et al., 2004; Kartavtsev et al., 2007). In studies of the Southern catfish that were based on these two mitochondrial genes, there was lower genetic diversity in the tributaries of the Yangtze River (Wang and Yu, 2008; Wang and Wang, 2009).

Recently, with the improvement of molecular techniques, it has become comparatively easier to obtain complete sequences of mitochondrial genome. The size of the mitochondrial genome ranges from 15 to $16 \mathrm{~kb}$, and consists of 13 protein-coding genes, 2 rRNA genes, 22 tRNA genes, and a non-coding control region (Boore, 1999). The mitochondrial genome of Siluriformes may therefore provide valuable information for population genetics analysis.

In the present study, we report the complete DNA sequence and structure of the mitochondrial genomes of the Southern catfish and Chinese catfish in the Wujiang River, a tributary of the Yangtze River. In combination with the mitochondrial genomes of other fishes (Table 1), phylogenetic relationships in the order Siluriformes were analyzed. To date, nine mitochondrial genomes of four species in the genus Silurus have been reported in GenBank, including four of $S$. asotus, and three of $S$. meridionalis (Table 1). Thus, genetic variation can be analyzed among 
different geographical populations. Our overall objective was to obtain additional information by evaluating the comparative genetic diversity of Southern and Chinese catfish in the wild.

Table 1. The information of mitochondrial genomes of fishes used in this study.

\begin{tabular}{|c|c|c|}
\hline Species & GenBank accession No. & Source Siluriformes \\
\hline Leiocassis longirostris & GU596454 & Wang et al. (2011) \\
\hline Leiocassis crassilabris & JX867257 & Liang et al. (2013) \\
\hline Pseudobagrus brevicaudatus & JX867256 & Liang et al. (2013) \\
\hline Pelteobagrus nitidus & HM746659 & Liang et al. (2012) \\
\hline Pseudobagrus ussuriensis & KC188782 & Wan et al. (2013) \\
\hline Pelteobagrus vachellii & HM746660 & Liang et al. (2012) \\
\hline Pelteobagrus eupogon & KJ001784 & Wang et al. (unpublished) \\
\hline Pseudobagrus truncatus & JX867259 & Liang et al. (unpublished) \\
\hline Pseudobagrus tokiensis & AB054127 & Saitoh et al. (2003) \\
\hline Pseudobagrus brevicorpus & HM355585 & Kim et al. (2011) \\
\hline Pelteobagrus fulvidraco & HM641815 & Liang et al. (2012) \\
\hline Pelteobagrus eupogon & JQ734476 & Wang et al. (2013) \\
\hline Hemibagrus macropterus & JF834542 & Zeng et al. (2012) \\
\hline Glyptothorax fokiensis & JQ917224 & Zhou et al. (2012) \\
\hline Liobagrus kingi & Kc193779 & Jia et al. (2013) \\
\hline Liobagrus nigricauda & KC316116 & Jia et al. (2013) \\
\hline Liobagrus marginatoides & Kc473938 & Jia et al. (2013) \\
\hline Ictalurus punctatus & AF482987 & Waldbieser et al. (2003) \\
\hline Cranoglanis bouderius & AY898626 & Peng et al. (2006) \\
\hline Pangasianodon gigas & AY762971 & Jondeung et al. (2007) \\
\hline Amphilius sp NM-2010 & AP012002 & Nakatani et al. (2011) \\
\hline Malapterurus electricus & $A P 012016$ & Nakatani et al. (2011) \\
\hline Centromochlus perugiae & AP012024 & Nakatani et al. (2011) \\
\hline Tetranematichthys quadrifilis & AP012025 & Nakatani et al. (2011) \\
\hline Amblydoras gonzalezi & AP012001 & Nakatani et al. (2011) \\
\hline Liobagrus reinii & AP012015 & Nakatani et al. (2011) \\
\hline Hara jerdoni & AP012012 & Nakatani et al. (2011) \\
\hline Pangasius larnaudii & AP012018 & Nakatani et al. (2011) \\
\hline Sciades seemanni & AP012003 & Nakatani et al. (2011) \\
\hline Auchenoglanis occidentalis & AP012005 & Nakatani et al. (2011) \\
\hline Pareutropius debauwi & AP012017 & Nakatani et al. (2011) \\
\hline Chrysichthys sp NM-2010 & AP012009 & Nakatani et al. (2011) \\
\hline Synodontis schoutedeni & AP012023 & Nakatani et al. (2011) \\
\hline Pimelodus pictus & AP012019 & Nakatani et al. (2011) \\
\hline Heteropneustes fossilis & AP012013 & Nakatani et al. (2011) \\
\hline Clarias sp NM-2010 & AP012010 & Nakatani et al. (2011) \\
\hline Chaca bankanensis & AP012008 & Nakatani et al. (2011) \\
\hline Plotosus japonicus & AP012020 & Nakatani et al. (2011) \\
\hline Bunocephalus coracoideus & AP012006 & Nakatani et al. (2011) \\
\hline Cetopsidium sp NM-2010 & AP012007 & Nakatani et al. (2011) \\
\hline Helogenes marmoratus & AP012014 & Nakatani et al. (2011) \\
\hline Diplomystes nahuelbutaensis & AP012011 & Nakatani et al. (2011) \\
\hline Trichomycterus areolatus & AP012026 & Nakatani et al. (2011) \\
\hline Astroblepus sp NM-2010 & AP012004 & Nakatani et al. (2011) \\
\hline Pterygoplichthys disjunctivus & AP012021 & Nakatani et al. (2011) \\
\hline Silurus glanis & AM398435 & Vittas et al. (2011) \\
\hline Silurus meridionalis & JX087350 & Wang et al. (this study) \\
\hline Silurus meridionalis & HQ907992 & Zhou et al. (unpublished) \\
\hline Silurus meridionalis & HM746661 & Liang et al. (unpublished) \\
\hline Silurus asotus & JX087351 & Wang et al. (this study) \\
\hline Silurus asotus & AP012022 & Nakatani et al. (2011) \\
\hline Silurus asotus & JX256247 & Wang et al. (unpublished) \\
\hline Silurus asotus & JN116720 & Zeng et al. (unpublished) \\
\hline Silurus lanzhouensis & JF895472 & Wang et al. (2012) \\
\hline Liobagrus obesus & DQ321752 & Kartavtsev et al. (2007) \\
\hline Corydoras rabauti & AB054128 & Saitoh et al. (2003) \\
\hline \multicolumn{3}{|l|}{ Outgroup } \\
\hline \multicolumn{3}{|l|}{ Cypriniformes } \\
\hline Crossostoma lacustre & M91245 & Tzeng et al. (1992) \\
\hline \multicolumn{3}{|l|}{ Clupeiformes } \\
\hline Sardinops melanostictus & AB032554 & Inoue et al. (2000) \\
\hline \multicolumn{3}{|l|}{ Characiformes } \\
\hline Phenacogrammus interruptus & AB054129 & Saitoh et al. (2003) \\
\hline
\end{tabular}




\section{MATERIAL AND METHODS}

\section{Fish samples and DNA extraction}

Samples of S. meridionalis and S. asotus were collected from the Wujiang River in Guizhou Province, China, and were identified according to their morphology, as previously described (Chen, 1977; Wu, 1989). Total genomic DNA was extracted from muscle tissue using a 3 S Spin Genomic DNA Miniprep Kit (Shanghai, China) following the manufacturer's protocol.

\section{PCR amplification and sequencing}

In a previous study on the mitochondrial genome of S. lanzhouensis (Wang Q. R. et al., 2012b) we designed 7 pairs of long and accurate polymerase chain reaction (LA-PCR) primers using primer premier 5.0. These primers were designed based on the complete mitochondrial genome of S. glanis (GenBank accession No. AM398435) and worked well for S. meridionalis, but not for S. asotus. Therefore, we designed eight pairs of LA-PCR primers specific for S. asotus. All primers are listed in Table 2. Some short fragments were amplified to link the long fragments, based on the sequences of those long fragments.

\begin{tabular}{|c|c|c|c|}
\hline Primer & Forward sequence & Reverse sequence & Size of fragment $(\mathrm{bp})$ \\
\hline \multicolumn{4}{|l|}{ S. meridionalis } \\
\hline Phe-ND2 & AATCAAAGCATAACACTG & GCTTATGAATGTGAGGGT & 4100 \\
\hline Met-CO II & TCTTATCAATGAGCCССTAC & GCTAATGCTAATCCCT & 3900 \\
\hline Ser-ND4L & TAGTTTCAAGCCAGTCA & TTCTGAGCACCATTTGAT & 3400 \\
\hline ND4L-ND4 & CCGCATTTACTCTGGGACT & TTGGCCTCTTTCGGTGGA & 1800 \\
\hline ND4-Cytb & CAGCСTACTСССTTTACC & TACTACGCCAATGTTTCA & 3000 \\
\hline ND6-Thr & TACTACGCCAATGTTTCA & CTCCGATCTCCGGATTACAAGAC & 1100 \\
\hline Cytb-12S & GCACTCCTGCTATCCATC & CGTTTCTAGGGTTCGT & 1800 \\
\hline \multicolumn{4}{|l|}{ S. asotus } \\
\hline Phe-Val & AATCAAAGCATAACACTG & TTTGCCTTTTCTGTCT & 1200 \\
\hline 12S-ND2 & AAAATAAGTGCCCGAAGG & TTGGATGGGTTAGACAGC & 3600 \\
\hline Gln-Lys & TCTTATCAATGAGCCCCTAC & GCTAATGCTAATCCCT & 3800 \\
\hline COII-ND4 & TAGAAACGGACCACCGAATA & TGGCTAGGCAGAAGAGGG & 3700 \\
\hline ND4-ND4 & GAGGCTATGGTATAATGCG & ATAAGGTTTGGTAGTGGG & 500 \\
\hline ND4-Glu & GCCTTATGAGGAATTGTC & TGAGTCAGCCGTAGTTTA & 3800 \\
\hline ND6-Thr & GACTTGAAAACCACCGTTG & CTCCGATCTCCGGATTACAAGAC & 1100 \\
\hline CYTB-12S & TTCATTCTACCATTCGCTAT & CTTTACGCCGTGTCTATT & 2500 \\
\hline
\end{tabular}

LA-PCR was carried out in a $50-\mu \mathrm{L}$ reaction volume containing $5 \mu \mathrm{L} 10 \mathrm{X}$ LA-PCR buffer II, $8 \mu \mathrm{L} 1.5 \mathrm{mM}$ dNTPs, $2 \mu \mathrm{L} 10 \mu \mathrm{M}$ of each primer, $0.5 \mu \mathrm{L}$ LA Taq polymerase (TaKaRa, Japan) and approximately $50 \mathrm{ng}$ of the template DNA. The thermal cycle profile included a pre-denaturation step at $94^{\circ} \mathrm{C}$ for $4 \mathrm{~min}, 40$ cycles of denaturation at $94^{\circ} \mathrm{C}$ for $60 \mathrm{~s}$, annealing at $50^{\circ} \mathrm{C} \mathrm{for} 60 \mathrm{~s}$, followed by an extension at $72^{\circ} \mathrm{C}$ for $5 \mathrm{~min}$, and a final extension at $72^{\circ} \mathrm{C}$ for $10 \mathrm{~min}$. The PCR mixture for the short fragments was the same as that described for the LA-PCR, with the exception that the extension time was changed to $1 \mathrm{~min}$ in the PCR program. PCR products were sent to Biosune Biotech Company (Beijing, China) for sequencing using primer walking. 


\section{Data analysis}

DNA sequences were corrected and analyzed using Sequencing Analysis v3.4.1 (Applied Biosystems, USA) and Seqman v5.05 (DNASTAR Inc., USA). The nucleotide sequences of the mitochondrial $12 S$ and $16 S$ rRNA genes, and the deduced amino acid sequences of each of the 13 complete mitochondrial protein-coding genes were aligned separately, using the default parameters of CLUSTAL X version 1.81 (Thompson et al., 1997). Alignments (available from the authors upon request) were then revised by sight, in an effort to maximize positional homology.

The combined protein data set was constructed after excluding gapped positions. The rRNA data set included both complete and partial sequences, and gaps were treated as missing data. Additionally, tRNA genes were identified by tRNAscan-SE 1.21 (Lowe and Eddy, 1997). The locations of the protein-coding genes and rRNA genes were identified, and compared with the known sequences of other catfish species, including S. glanis (GenBank accession No. AM398435) and Pangasianodon gigas (GenBank accession No. AY762971) (Jondeung et al., 2007).

We reconstructed phylogenetic relationships of the order Siluriformes with the maximum likelihood method using RAxML 8.0X (Stamatakis, 2006) and MEGA 5 (Tamura and Peterson, 2011), respectively. The DNA sequences of all 13 mitochondrial protein-coding genes were used for the analysis. The species used in the analysis are listed in Table 1.

\section{RESULTS AND DISCUSSION}

\section{Structure of the mitochondrial genome}

The complete mitochondrial genomes of $S$. meridionalis and $S$. asotus were obtained and are deposited in GenBank with the accession Nos. JX087350 and JX087351, respectively. The total length of the complete mitochondrial genome of $S$. meridionalis and $S$. asotus was 16,526 and $16,525 \mathrm{bp}$, respectively. The gene order and gene coding strand of $S$. meridionalis and $S$. asotus were identical to those of the Atlantic cod, the Javeline goby, and the Japanese flying fish (Johansen and Bakke, 1996; Kim et al., 2004; Nagase et al., 2005), consisting of 2 rRNAs, 22 tRNAs, 13 protein-coding genes, and a control region (Figure 1 and Table 3). The overall base composition of the $\mathrm{H}$-strand was A: $30.3 \%$, C: $28.7 \%$, G: $16.0 \%$, and $\mathrm{T}: 25.0 \%$ in S. meridionalis, and A: $30.5 \%$, C: $27.9 \%$, G: $15.8 \%$, and T: $25.8 \%$ in S. asotus.

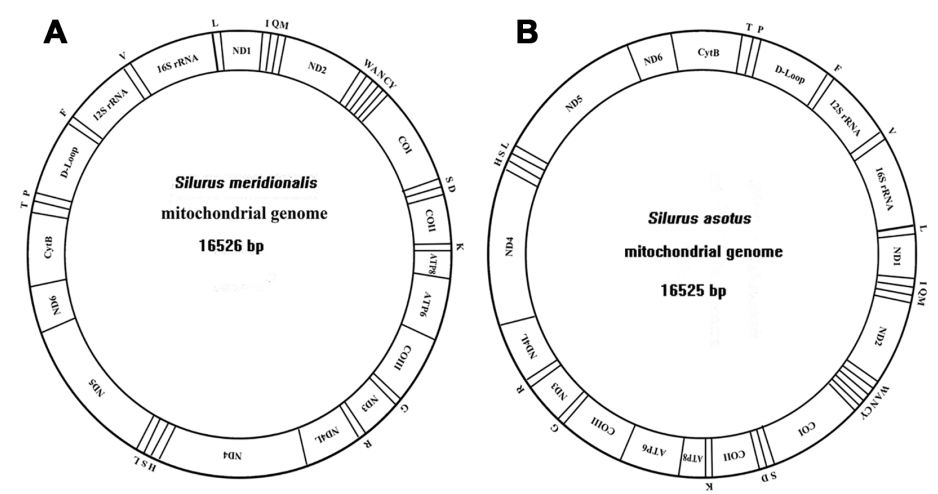

Figure 1. Gene organization for the mitochondrial genomes of S. meridionalis (A) and S. asotus (B). 


\begin{tabular}{|c|c|c|c|c|c|c|c|c|}
\hline \multirow[t]{2}{*}{ Gene/element } & \multicolumn{4}{|c|}{ S. asotus } & \multicolumn{4}{|c|}{ S. meridionalis } \\
\hline & Abbreviation & Strand & Position & Size & Position & Size & Start codon & Stop codon \\
\hline tRNA ${ }^{\text {Phe }}$ & $\mathrm{F}$ & $\mathrm{H}$ & $1-70$ & 70 & $1-70$ & 70 & & \\
\hline $12 S$ ribosomal RNA & $12 S$ & H & $71-1022$ & 952 & $71-1023$ & 953 & & \\
\hline tRNA ${ }^{\text {val }}$ & $\mathrm{V}$ & $\mathrm{H}$ & $1023-1094$ & 72 & 1024-1095 & 72 & & \\
\hline 16 S ribosomal RNA & $16 \mathrm{~S}$ & $\mathrm{H}$ & $1095-2769$ & 1675 & 1096-2771 & 1676 & & \\
\hline tRNA $A^{\text {Leu }}$ & $\mathrm{L}$ & H & $2770-2844$ & 75 & $2772-2846$ & 75 & & \\
\hline NADH dehydrogenase subunit 1 & ND1 & H & $2845-3819$ & 975 & $2847-3821$ & 975 & ATG & TAA \\
\hline tRNA $A^{1 / e}$ & I & H & $3821-3892$ & 72 & $3823-3894$ & 72 & & \\
\hline tRNA ${ }^{\mathrm{Gln}}$ & $Q$ & L & $3962-3892$ & 71 & $3894-3964$ & 71 & & \\
\hline tRNA & M & $\mathrm{H}$ & $3962-4030$ & 69 & $3964-4032$ & 69 & & \\
\hline NADH dehydrogenase subunit 2 & ND2 & $\mathrm{H}$ & $4031-5077$ & 1047 & $4033-5079$ & 1047 & ATG & TAG \\
\hline tRNA $A^{\text {Tp }}$ & w & H & $5076-5146$ & 71 & $5078-5148$ & 71 & & \\
\hline tRNA Ala & $A$ & L & $5149-5217$ & 69 & $5151-5219$ & 69 & & \\
\hline tRNA ${ }^{A s n}$ & $\mathrm{~N}$ & $\mathrm{~L}$ & $5219-5291$ & 73 & $5221-5293$ & 73 & & \\
\hline tRNA ${ }^{\text {cys }}$ & C & L & $5326-5392$ & 67 & $5328-5393$ & 66 & & \\
\hline tRNA $^{\text {Tyt }}$ & $\mathrm{Y}$ & L & $5397-5466$ & 70 & $5398-5467$ & 70 & & \\
\hline Cytochrome c oxidase subunit 1 & $\mathrm{COI}$ & $\mathrm{H}$ & $5468-7018$ & 1551 & $5469-7019$ & 1551 & GTG & TAG(TAA) \\
\hline tRNA $A^{\text {Ser }}$ & S & L & $7019-7089$ & 71 & $7020-7090$ & 71 & & \\
\hline tRNA Asp & $\mathrm{D}$ & $\mathrm{H}$ & $7094-7165$ & 72 & $7095-7166$ & 72 & & \\
\hline Cytochrome $\mathrm{c}$ oxidase subunit 2 & COII & H & $7179-7869$ & 691 & $7180-7870$ & 691 & ATG & T- \\
\hline tRNA ${ }^{\text {Lys }}$ & $\mathrm{K}$ & H & $7870-7943$ & 74 & $7871-7944$ & 74 & & \\
\hline ATP synthase F0 subunit 8 & ATP8 & H & $7945-8112$ & 168 & $7946-8113$ & 168 & ATG & TAA \\
\hline ATP synthase F0 subunit 6 & ATP6 & $\mathrm{H}$ & $8103-8786$ & 684 & $8104-8787$ & 684 & ATG & TAA \\
\hline Cytochrome $\mathrm{c}$ oxidase subunit 3 & COIII & $\mathrm{H}$ & 8786-9569 & 784 & $8787-9570$ & 784 & ATG & $\mathrm{T}-$ \\
\hline tRNA ${ }^{\text {Gly }}$ & G & H & $9570-9642$ & 73 & $9571-9643$ & 73 & & \\
\hline NADH dehydrogenase subunit 3 & ND3 & H & $9643-9993$ & 351 & $9644-9994$ & 351 & ATG & TAG \\
\hline tRNA $A^{A r g}$ & $\mathrm{R}$ & H & $9992-10062$ & 71 & $9993-10063$ & 71 & & \\
\hline NADH dehydrogenase subunit 4L & ND4L & $\mathrm{H}$ & $10063-10359$ & 297 & $10064-10360$ & 297 & ATG & TAA \\
\hline NADH dehydrogenase subunit 4 & ND4 & $\mathrm{H}$ & $10353-11733$ & 1381 & $10354-11734$ & 1381 & ATG & T- \\
\hline tRNA $A^{\text {His }}$ & $\mathrm{H}$ & $\mathrm{H}$ & $11734-11803$ & 70 & $11735-11804$ & 70 & & \\
\hline tRNA ${ }^{\text {Ser }}$ & S & $\mathrm{H}$ & $11804-11869$ & 66 & $11805-11870$ & 66 & & \\
\hline tRNA ${ }^{\text {Leu }}$ & $\mathrm{L}$ & H & $11873-11945$ & 73 & $11874-11946$ & 73 & & \\
\hline NADH dehydrogenase subunit 5 & ND5 & H & $11946-13772$ & 1827 & $11947-13773$ & 1827 & ATG & TAA \\
\hline NADH dehydrogenase subunit 6 & ND6 & L & $13768-14287$ & 519 & $13769-14288$ & 520 & ATG & TAA \\
\hline tRNA $A^{\text {Glu }}$ & $\mathrm{E}$ & L & $14288-14356$ & 69 & $14289-14357$ & 69 & & \\
\hline Cytochrome b & cyt b & H & $14358-15495$ & 1138 & $14359-15496$ & 1138 & ATG & T- \\
\hline tRNA ${ }^{\text {Thr }}$ & $\mathrm{T}$ & $\mathrm{H}$ & $15496-15566$ & 71 & $15497-15567$ & 71 & & \\
\hline tRNAPro & $P$ & L & $15565-15634$ & 70 & $15566-15635$ & 70 & & \\
\hline Displacement loop (control region) & D-loop & $\mathrm{H}$ & $15635-16525$ & 891 & $15636-16526$ & 891 & & \\
\hline
\end{tabular}

The protein-coding genes in the mitochondrial genomes of $S$. meridionalis and $S$. asotus utilized ATG as the start codon, except for COI, which initiated with GTG (Table 3). These findings are similar to those for the dogfish, the Chinese longsnout catfish, and the black carp (Delarbre et al., 1998; Wang et al., 2011, 2012a). Nine open reading frames ended with TAA or TAG, while each of the others had an incomplete stop codon $\mathrm{T}$ (Table 3 ). The stop codon of the protein-coding genes was the same between the two species, except for COI, which ended with TAA in S. meridionalis, and TAG in S. asotus. In addition, overlapping sequences were found in ATP8-ATP6 (10 bp) and ND4-ND4L (7 bp), which occurred on the same strand, and in ND5-ND6 (5 bp), which occurred on different strands, in both $S$. meridionalis and $S$. asotus.

The mitochondrial genome of $S$. meridionalis and $S$. asotus contained 22 tRNA genes, which ranged from 66 to $75 \mathrm{bp}$ in size. All tRNA genes, with the exception of tRNA ${ }^{\text {Ser }}$ (AGY), were predicted to fold into the typical cloverleaf secondary structure with normal base pairing. Among these tRNA genes, eight genes were encoded on the L-strand, while the others were encoded on the H-strand. The 12S rRNA genes in S. meridionalis and S. asotus were 953 and $952 \mathrm{bp}$, respectively, and the $16 S$ rRNA genes were 1676 and 1675 bp, respectively. As in other vertebrates 
(Inoue et al., 2000; Wang et al., 2011, 2012a), 12S and 16S rRNA genes were located between the tRNA $^{\text {Phe }}$ and tRNA ${ }^{\text {Leu }}$ genes, and separated by the tRNA ${ }^{\text {Val }}$ gene.

The control region, which is the major non-coding region in the mitochondrial genome, regulates replication and transcription (Thompson et al., 1997; Saitoh et al., 2003). The length of the control region was $891 \mathrm{bp}$ in both S. meridionalis and S. asotus. In comparison to other species of fish (Xu et al., 2011; Kim et al., 2005), three conserved sequence block (CSB) domains were found in the control region of S. meridionalis and S. asotus: CSB-1 at the 5' end; and CSB-2 and CSB-3 at the $3^{\prime}$ end.

\section{Phylogenetic analysis}

Phylogenetic relationships of S. meridionalis and S. asotus in the order Siluriformes are shown in Figure 2.
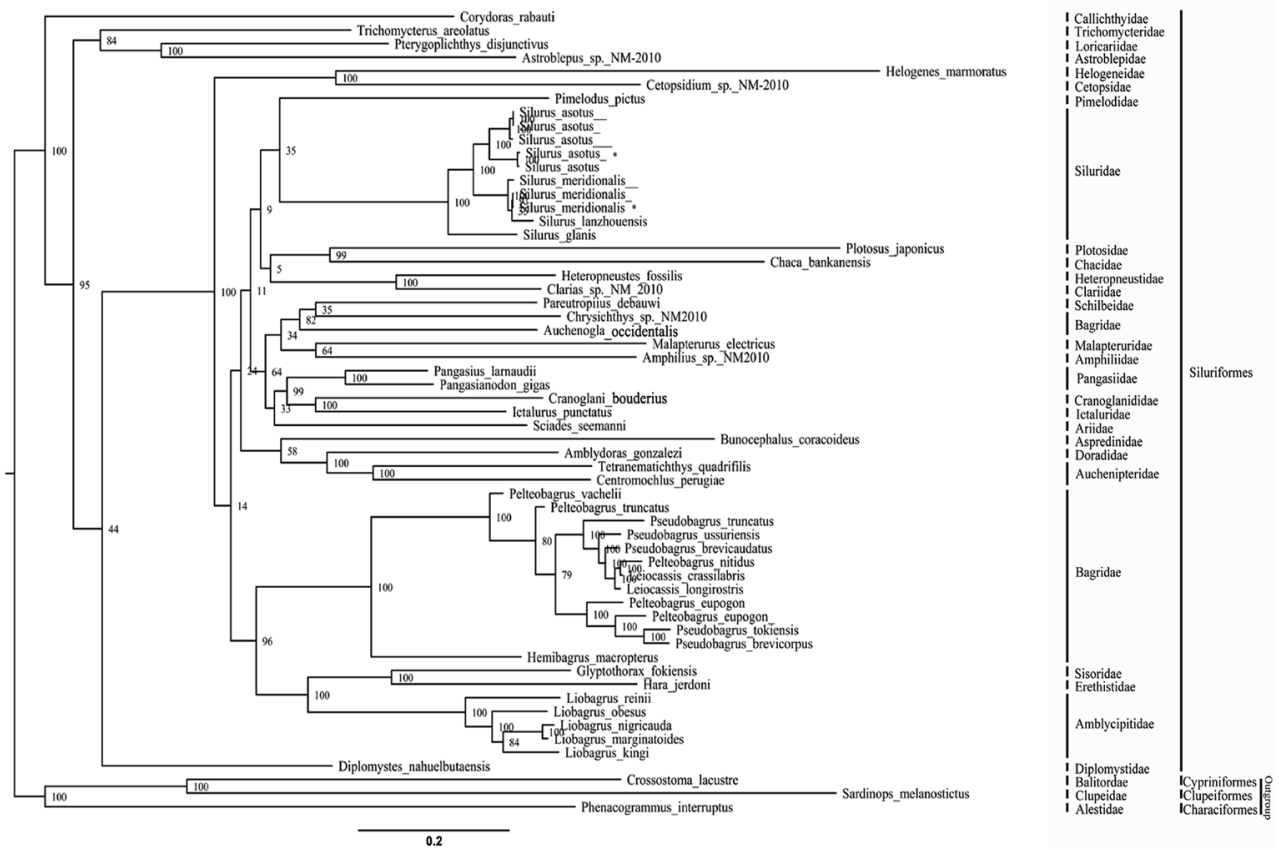

Figure 2. Phylogenetic relationships among Siluriformes by RAxML. Majority rule consensus of maximum likelihood bootstrap measure trees from RAxML inference analysis based on rRNA and protein code data set under the GTR+I+G (General Time Reversible; I: invariable sites; G: gamma distribution) model is shown. Branch lengths are mean estimates. Asterisks indicate specimens used in the present study. Numbers in the nodes are from highest to lowest bootstrap value. The scale in the left lower corner indicates relative branch lengths.

Four species of catfish in the family Siluridae formed a distinct clade with a high bootstrap value (100). This is consistent with the previously determined morphological classification of the family Siluridae and its significant differentiation from other families in the order Siluriformes (Chen, 1977). As expected, the monophyly of Siluriformes, and the inclusion of S. meridionalis and S. asotus within this order was highly supported (bootstrap value of 100 ). 
Siluridae was recovered with maximal support as a sister group of Pimelodus pictus (Pimelodidae), which is consistent with the previous report (Nakatani et al., 2011). The families of Plotosidae, Chacidae, Heteropneustidae and Clariidae, were also recovered as sister groups; however, these relationships were not as well supported (bootstrap value of 9).

In other branches, the families of Schilbeidae, Malapteruridae, Amphiliidae, Cranoglanididae, Pangasiidae, Ariidae, and Ictaluridae formed a distinct group. The families of Bagridae and Amblycipitidae were strongly supported (bootstrap value of 96) as a sister group. However, Chrysichthys sp NM2010 and Auchenoglanis occidentalis are excluded from Bagridae.

Even though phylogenetic interrelationships of highly diversified families of the order Siluriformes, such as Loricariidae, Trichomycteridae, Astroblepidae, and Callichthyidae, are well studied at the molecular level, the main phylogenetic interrelationships of siluriform families remain largely unresolved. Corydoras rabauti (Callichthyidae), which is assigned to the suborder Loricarioidei, was placed as a sister group of all other analyzed siluriforms. The family Callichthyidae is an independent clade in the Siluriformes.

The phylogenetic relationship of the families in the Siluriformes obtained from this study was similar to another study based on the entire mitochondrial genome excluding the control region (Wang et al., 2011). At a higher taxonomic level, the monophyly of Otophysi (Cypriniformes, Gymnotiformes, Characiformes, and Siluriformes) was highly supported (bootstrap value of 100) by all methods of phylogenetic inference. We inferred therefore that Siluriformes originate from Characiformes. The monophyly of the different orders within Ostariophysi is well supported based on morphological grounds.

In the phylogenetic tree reestablished with MEGA 5 (Figure 3), four species of catfish in the family Siluridae formed a distinct clade with a high posterior probability (bootstrap value of 100). The families of Mochokidae, Schibeidae, and Bagridae (Chrysichthy sp NM2010 and Auchenoglanis) were recovered as sister groups. However, their relationship was not very well supported (bootstrap value of 7). This differs from our analysis based on the RAxML tree (Figure 2).

The families Loricariidae, Trichomycteridae, and Astroblepidae constituted a group. Consistent with our results based on the RAxML tree, Corydoras rabauti (Callichthyidae), which is assigned to the suborder Loricarioidei, was placed as a sister group of all other analyzed siluriforms. The family Callichthyidae was an independent clade in the Siluriformes (bootstrap value of 100).

In general, both trees formed with RAxML and MEGA support the fact that the family Callichthyidae was an independent clade in the Siluriformes. At a higher taxonomic level, the monophyly of Otophysi (Cypriniformes, Gymnotiformes, Characiformes, and Siluriformes) was highly supported (bootstrap value of 100 ), by all methods of phylogenetic inference. Siluriformes was found to originate from Characiformes.

\section{Nucleotide variation}

When the mitochondrial genome of $S$. meridionalis obtained in the present study was compared with two others submitted to GenBank (Table 4), among the 16536 bp aligned sequences, $1.5 \%$ of the sites were variable. The genes of rRNA $(1.0 \%)$ and tRNA $(0.5 \%)$ were more conserved, whereas the control region was more variable $(6.2 \%)$. The percentage of variable sites in all 13 protein-coding genes was $1.4 \%$, and this value ranged from $0.3 \%$ (COII) to $2.2 \%$ (ND2) in one of 13 protein-coding genes. 


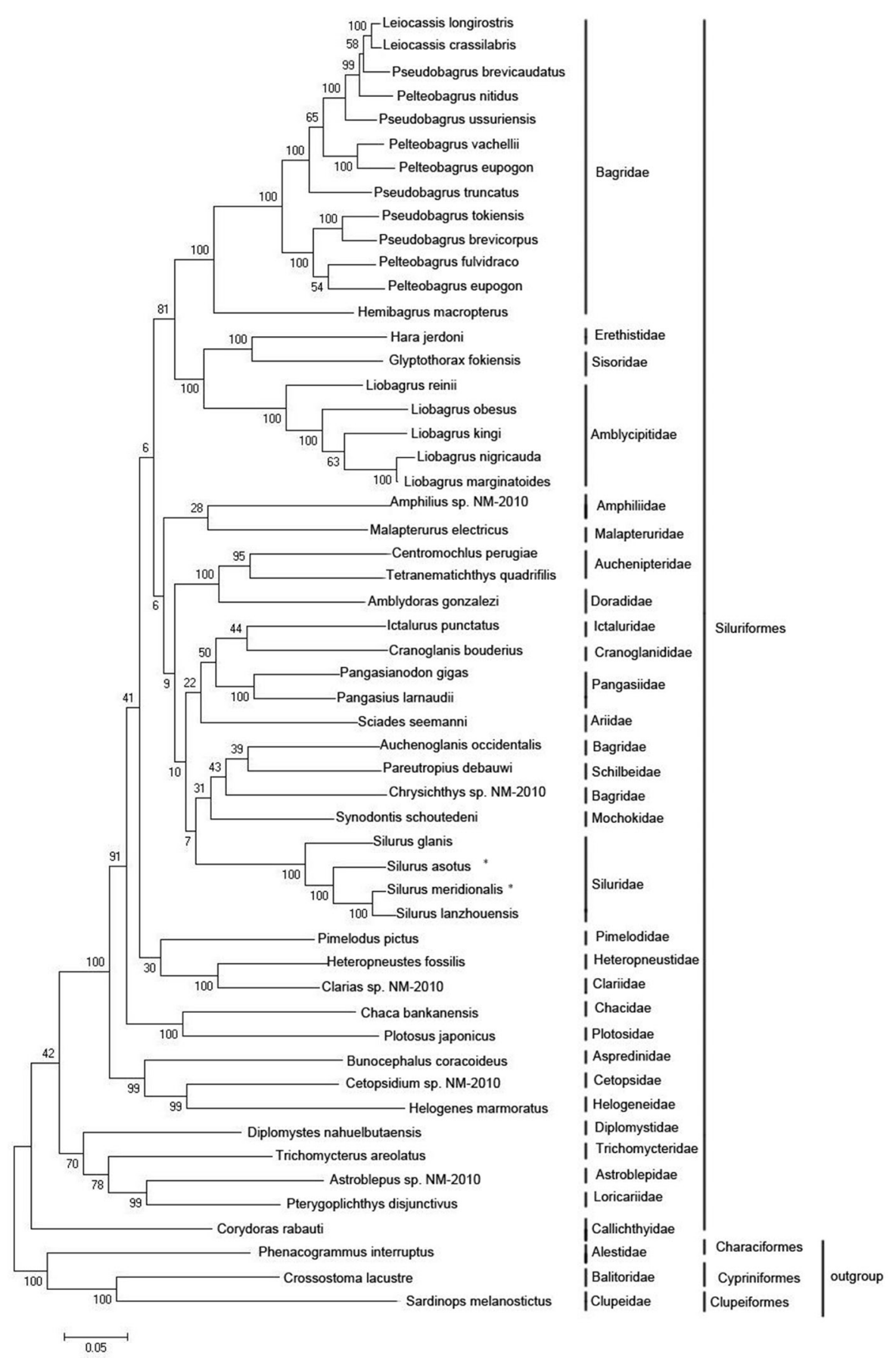

Figure 3. Phylogenetic relationships of fishes in the order Siluriformes based on 13 mitochondrial protein-coding genes and analyzed with the maximum likelihood method in MEGA 5. Repetition frequencies (posterior probabilities) for $\mathrm{N}=$ 500 simulated generations are shown in the nodes. The scale in the lower left corner indicates relative branch lengths. 
Table 4. Intraspecific variation of mitochondrial genomes of 3 individuals of Silurus asotus and Silurus meridionalis.

\begin{tabular}{|c|c|c|c|c|c|c|}
\hline & \multicolumn{3}{|c|}{ S. asotus } & \multicolumn{3}{|c|}{ S. meridionalis } \\
\hline & $\begin{array}{l}\text { Length of } \\
\text { aligned sequence }\end{array}$ & $\begin{array}{c}\text { Number of } \\
\text { variable sites }\end{array}$ & $\begin{array}{c}\text { Percentage of } \\
\text { variable sites (\%) }\end{array}$ & $\begin{array}{l}\text { Length of } \\
\text { aligned sequence }\end{array}$ & $\begin{array}{c}\text { Number of } \\
\text { variable sites }\end{array}$ & $\begin{array}{c}\text { Percentage of } \\
\text { variable sites (\%) }\end{array}$ \\
\hline All sites & 16533 & 873 & 5.3 & 16536 & 250 & 1.5 \\
\hline tRNAs & 1665 & 49 & 2.9 & 1568 & 8 & 0.5 \\
\hline rRNAs & 2631 & 67 & 2.5 & 2630 & 27 & 1.0 \\
\hline Control region & 892 & 84 & 9.4 & 900 & 56 & 6.2 \\
\hline Protein-coding genes & 11391 & 673 & 5.9 & 11391 & 159 & 1.4 \\
\hline ND1 & 975 & 65 & 6.7 & 975 & 18 & 1.8 \\
\hline ND2 & 1047 & 65 & 6.2 & 1047 & 23 & 2.2 \\
\hline COI & 1551 & 87 & 5.6 & 1551 & 17 & 1.1 \\
\hline coll & 691 & 24 & 3.5 & 691 & 2 & 0.3 \\
\hline ATP8 & 168 & 5 & 3.0 & 168 & 1 & 0.6 \\
\hline ATP6 & 684 & 41 & 6.0 & 684 & 11 & 1.6 \\
\hline COIII & 784 & 38 & 4.8 & 784 & 9 & 1.1 \\
\hline ND3 & 351 & 17 & 4.8 & 351 & 4 & 1.1 \\
\hline ND4L & 297 & 12 & 4.0 & 297 & 2 & 0.7 \\
\hline ND4 & 1381 & 100 & 7.2 & 1381 & 23 & 1.7 \\
\hline
\end{tabular}

The level of intraspecific variation in $S$. asotus was much higher than that found in $S$. meridionalis. The percentage of variable sites, out of the $16,533 \mathrm{bp}$ aligned sequences, was $5.3 \%$ in S. asotus. The levels of variation in the rRNA and tRNA genes were 2.5 and $2.9 \%$, respectively. The level of variation in the control region was $9.4 \%$. The mean percentage of variable sites in all 13 protein-coding genes was $5.9 \%$, and ranged from $3.0 \%$ (ATP8) to $7.3 \%$ (ND6).

The great differences in intraspecific variation between $S$. meridionalis and $S$. asotus can be attributed to the source of the specimens. Although the source of specimens of two individuals of S. meridionalis (GenBank accession Nos. HM746661 and HQ907992) that have been deposited in GenBank is not described, it is reasonable to assume that these specimens were both collected in the Yangtze River. This assumption is based on the fact that the institutes of the respective authors are both located near the Yangtze River.

The specimen of $S$. meridionalis in this study was collected from the Wujiang River, which is a branch of the Yangtze River. Hence, all three individuals of $S$. meridionalis under study were probably sampled from the Yangtze River. In contrast, the specimen of $S$. asotus in the present study was sampled from the Wujiang River. GenBank accession No. JX256427 was sampled from the Sichuan River, and GenBank accession No. JN116720 was sampled from the Hechuan district. The Wujiang River, the Sichuan, and the Hechuan are drainage basins for the Yangtze River. Another mitochondrial genome of S. asotus (GenBank accession No. AP012022) was submitted by Japanese researchers (Nakatani et al., 2011). Thus, we believe that catfish species should be collected in rivers of Japan. Higher levels of geographical isolation will probably be sufficient to explain the higher level of genetic divergence of both specimens of S. asotus in the present study.

\section{ACKNOWLEDGMENTS}

We thank Ms. Yang Xiurong for collecting samples in the field. This work is supported by the key project of Science \& Technology Department of Guizhou Province [Qiankehe NZ(2013)3027], and the important scientific project in "125" Program of Guizhou Province [Qianjiaohe (2013)025]. 


\section{REFERENCES}

Boore JL (1999). Animal mitochondrial genomes. Nucleic Acids Res. 27: 1767-1780.

Chen HL (1977). A Review of the Chinese Siluridae. Hydrobiol. Collected Papers 6: 197-216.

Chu XL, Zheng BS and Dai DY (1999). Fauna Sinica, Class Teleostei, Siluriformes. Science Press, Beijing, 5-77.

Delarbre C, Spruyt N, Delmarre C, Gallut C, et al. (1998). The complete nucleotide sequence of the mitochondrial DNA of the dogfish, Scyliorhinus canicula. Genetics 150: 331-344.

Hong XJ and Liu Y (1998). The isozyme preliminary analysis for different age SME-1 cells and epithelial tissue of S. meridionalis. In: Sichuan Economy Catfish. Southwest Normal University Publishing Company, Chongqing.

Inoue JG, Miya M, Tsukamoto K and Nishida M (2000). Complete mitochondrial DNA sequence of the Japanese sardine Sardinops melanostictus. Fish. Sci. 66: 924-932.

Johansen S and Bakke I (1996). The complete mitochondrial DNA sequence of Atlantic cod (Gadus morhua): relevance to taxonomic studies among codfishes. Mol. Mar. Biol. Biotechnol. 5: 203-214.

Jondeung A, Sangthong P and Zardoya R (2007). The complete mitochondrial DNA sequence of the Mekong giant catfish (Pangasianodon gigas), and the phylogenetic relationships among Siluriformes. Gene 387: 49-57.

Kartavtsev YP, Jung SO, Lee YM, Byeon HK, et al. (2007). Complete mitochondrial genome of the bullhead torrent catfish, Liobagrus obesus (Siluriformes, Amblycipididae): Genome description and phylogenetic considerations inferred from the Cyt b and 16S rRNA genes. Gene 396: 13-27.

Kim IC, Kweon HS, Kim YJ, Kim CB, et al. (2004). The complete mitochondrial genome of the javeline goby Acanthogobius hasta (Perciformes, Gobiidae) and phylogenetic considerations. Gene 336: 147-153.

Kim IC, Jung SO, Lee YM, Lee CJ, et al. (2005). The complete mitochondrial genome of the rayfish Raja porosa (Chondrichthyes, Rajidae). DNA Seq. 16: 187-194.

Li XM, Cao ZD and Fu SJ (2010). The effect of exercise training on the metabolic interaction between feeding and locomotion in the juvenile southern catfish (Silurus meridionalis Chen). J. Exp. Zool. A Ecol. Genet. Physiol. 313: 557-563.

Li XY, Wang DZ, Zhou Y and Lu J (2009). RAPD Analysis on nDNA of Silurus asotus. J. Henan Normal Univ. (Nat. Sci.) 37: 177-179.

Lowe TM and Eddy SR (1997). tRNAscan-SE: a program for improved detection of transfer RNA genes in genomic sequence. Nucleic Acids Res. 25: 955-964.

Moore WS (1995). Inferring phylogenies from mtDNA variation: Mitochondrial-gene trees versus nuclear-gene trees. Evolution 49: 718-726.

Nagase M, Aimi T, Suginaka K, Kitamoto Y, et al. (2005). Complete mitochondrial DNA sequence of the Japanese flying fish Cypselurus hiraii. Fish. Sci. 71: 914-923.

Nakatani M, Miya M, Mabuchi K, Saitoh K, et al. (2011). Evolutionary history of Otophysi (Teleostei), a major clade of the modern freshwater fishes: Pangaean origin and Mesozoic radiation. BMC Evol. Biol. 11: 177.

Peng Z, He S and Zhang Y (2004). Phylogenetic relationships of glyptosternoid fishes (Siluriformes: Sisoridae) inferred from mitochondrial cytochrome b gene sequences. Mol. Phylogenet. Evol. 31: 979-987.

Saitoh K, Miya M, Inoue JG, Ishiguro NB, et al. (2003). Mitochondrial genomics of ostariophysan fishes: perspectives on phylogeny and biogeography. J. Mol. Evol. 56: 464-472.

Shirai N, Higuchi T and Suzuki H (2006). Analysis of lipid classes and the fatty acid composition of the salted fish roe food products, Ikura, Tarako, Tobiko and Kazunoko. Food Chem. 94: 61-67.

Stamatakis A (2006). RAxML-VI-HPC: maximum likelihood-based phylogenetic analyses with thousands of taxa and mixed models. Bioinformatics 22: 2688-2690.

Tamura KD and Peterson D (2011). MEGA5: molecular evolutionary genetics analysis using maximum likelihood, evolutionary distance, and maximum parsimony methods. Mol. Biol. Evol. 28: 2731-2739.

Thompson JD, Gibson TJ, Plewniak F, Jeanmougin F, et al. (1997). The CLUSTAL_X windows interface: flexible strategies for multiple sequence alignment aided by quality analysis tools. Nucleic Acids Res. 25: 4876-4882.

Wang C, Wang J, Yang J, Lu G, et al. (2012a). Complete mitogenome sequence of black carp (Mylopharyngodon piceus) and its use for molecular phylogeny of leuciscine fishes. Mol. Biol. Rep. 39: 6337-6342.

Wang J, Shen T, Ju J and Yang G (2011). The complete mitochondrial genome of the Chinese longsnout catfish Leiocassis longirostris (Siluriformes: Bagridae) and a time-calibrated phylogeny of ostariophysan fishes. Mol. Biol. Rep. 38: 2507-2516.

Wang QR and Yu XD (2008). Sequence Conservation of Cytochrome b Gene of Silurus merdionalis. J. Southwest Univ. (Nat. Sci. Edn.) 30: 138-142.

Wang QR and Wang DZ (2009). Mitochondrial DNA 16SrRNA gene sequence and genetic diversity of Silurus meridionalis. Guizhou Agric. Sci. 37: 132-135.

Wang QR, Xu C, Xu CR and Wang RJ (2012b). Mitochondrial genome structure of yellow river catfish (Silurus lanzhouensis) 
and phylogenetic analysis. Acta Sci. Nat. Univ. Pekinensis 48: 376-380.

Wei G and Luo XC (1998). The Studied Artificial Propagation of S. asotus. In: Sichuan Economy Catfish. Southwest China Normal University Publishing Company, Chongqing, 294-298.

Wu L (1989). The Fishes of Guizhou Province. People's Publishing House of Guizhou, Guiyang.

Xu TJ, Cheng YZ, Sun YN, Shi G, et al. (2011). The complete mitochondrial genome of bighead croaker, Collichthys niveatus (Perciformes, Sciaenidae): structure of control region and phylogenetic considerations. Mol. Biol. Rep. 38: 4673-4685.

Yoon JM and Kim JY (2004). Genetic Differences within and between Populations of Korean Catfish (S. asotus) and Bullhead (P. fulvidraco) Analysed by RAPD-PCR. Asian-Aust. J. Anim. Sci. 17: 1053-1061.

Zhang W, Cao ZD, Peng JL, et al. (2010). The effects of dissolved oxygen level on the metabolic interaction between digestion and locomotion in juvenile southern catfish (Silurus meridionalis Chen). Comp. Biochem. Physiol. Part A-Mol. Integr. Physiol. 157: 212-219. 